\title{
Assessment of Impact Rainfall Variability on Water Supply in Ibadan South West Local Government Area, Oyo State, Nigeria
}

\author{
ADETAYO, AO \\ Institute of Agricultural Research and Training, Obafemi Awolowo University, P. M. B. 5029, Ibadan, Oyo State, Nigeria \\ Email: wale_agromet@yahoo.com
}

\begin{abstract}
The effect of rainfall variability on water supply in Ibadan South West L.G.A was investigated in this study. Data collected were analyzed using descriptive statistics, correlation and regression analysis. The result of the analysis shows that there is a weak positive relationship between annual rainfall received and the public water supply in the study area during the selected (2006-2020) years. The results obtained from the computation of correlation were used to test for the validity of the first hypothesis. It was discovered that water demand by each household is almost similar from zone to zone which shows that the people are with similar water needs with $52.92 \%$ of the population needing 401 to 600 liters of water per day while $10.48 \%$ consumes over 800 liters of water per day The result also shows that the calculated value (3.807) is greater than the tabulated value (2.167). Therefore we reject the null hypothesis which states that there is no relationship between rural water supply and rainfall variability in the study area to accept the alternative hypothesis which states that there is a relationship between rural water supply and rainfall variability in the study area confirming that water availability and water supply is vulnerable to climate change and rainfall variability. The study recommends that the people, civil society organizations, government as well as non-governmental organizations should rededicate their efforts of ameliorating the adverse effect of climatic change and rainfall variability on water supply through massive development of ground water sources and rain harvesting techniques.
\end{abstract}

\section{DOI: https://dx.doi.org/10.4314/jasem.v25i8.15}

Copyright: Copyright (C) 2021 Adetayo. This is an open access article distributed under the Creative Commons Attribution License (CCL), which permits unrestricted use, distribution, and reproduction in any medium, provided the original work is properly cited.

Dates: Received: 10 May 2021; Revised: 28 June 2021; Accepted: 01 July 2021

Keywords: Water supply, Water demand, Climate change, Water adequacy level, Rainfall distribution pattern.

Water makes life possible as without water, life and civilization cannot develop or survive. Water is a vital need to man just as air and food are. In fact, apart from air that we breathe, water is the most important element to man. An average man requires about 1.5litres of water daily for drinking. Apart from drinking, man requires water for various other uses such as cooking, washing, sanitation, agriculture, industrial production and hydroelectric power generation, etc. As the standard of living increases, so does the need for demand for water increases. International Water Management Institute (IWMI, 2007) conducted an assessment of water management and found that one fifth of the world's people live in areas of physical water scarcity, one third of the world's population does not have access to clean water and that 1.6 billion people live in areas experiencing economic water scarcity. The only natural input to other sources of water (surface and ground water) is rainfall. The total quantity of water available at any given time is an important consideration. Rainfall is relied on for both surface and groundwater (Taylor, 2011). Long term fluctuations in rainfall distribution pattern around the world have been linked to the effects of climate change (Scott, 2004) and Taylor
(2011) which underscores the point that climate change will affect rainfall distribution and weather patterns. Climate change is a powerful force in shaping the life of poor people. Climate change has caused a shift in the seasonal variability of rainfall and thus a shift in the normal timing and length of wet and dry season and increase in seasonal fluctuation of the water bodies (Odjugo, 2010).

In Nigeria, changing rainfall patterns have been observed by various scientists. Anyadike (1993), Nnaji (2001) and Adjugo (2009) observed an unusual changes in the occurrence of wet and dry season regimes. The situation of water supply and management in Nigeria is complex as majority of people are poor and have sometimes have to travel several distances in order to get portable water for their household (Nnodu, 2008). An understanding of the dynamic relationship between rainfall variability and water supply is critical to developing future water projects.

In view of the above, this study is aimed at investigating how rainfall variability impacted water 
supply in Ibadan Southwest Local Government area of Oyo State, Nigeria.

\section{MATERIALS AND METHODS}

Ibadan Southwest Local Government is one of the 33 local government areas in Oyo State. Nigeria and is about $234 \mathrm{~m}$ above the sea level. It is within the forest savannah eco-climatic zone. It has an average annual rainfall of about $1225 \mathrm{~mm}$, average annual maximum and minimum temperature of $34.8^{\circ} \mathrm{C}$ and $24.3^{\circ} \mathrm{C}$ respectively. The raining season commences around the end of the third dekad of March and ends around the first dekad of November. The area is mainly drained by Ona River, which is characterized by dry valleys that are usually covered by flood during the periods of high rainfall. Ibadan Southwest has many autonomous communities: Apata, Odo-Ona, Dugbe, Aleshinloye to mention but few (Figure 1). The area is densely populated with about 282,585 inhabitants and landed area of $40 \mathrm{~km}^{2}$ (NPC, 2006). The economic activities include farming, trading, commercial services and civil service.

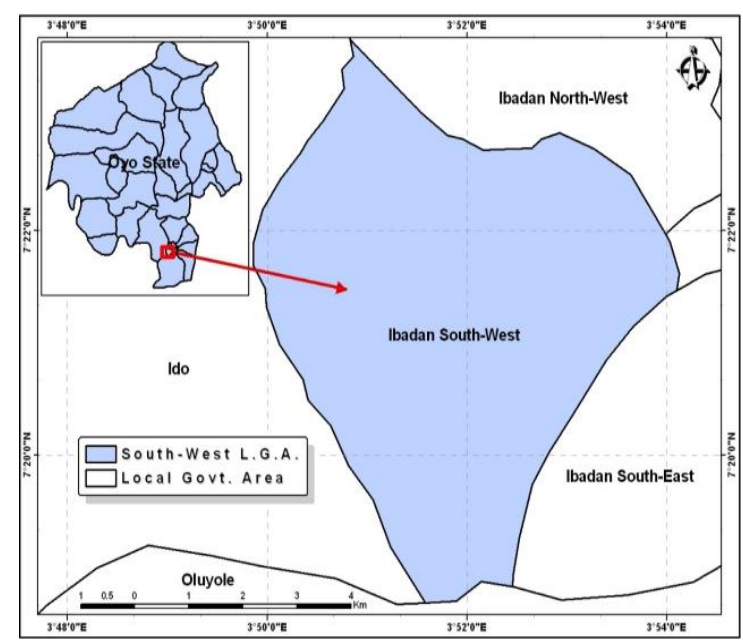

Fig 1: Map of Oyo State showing the study area.
Data were collected from primary sources using questionnaire, oral interviews and personal observation. This includes data on water demand sources of water supply and water adequacy level. Within the local government area, communities were randomly selected to ensure a representative coverage. A total of six communities were selected and 40 structured questionnaires were distributed among the randomly selected households to make a total of 240 pieces of the questionnaire. Secondary data, such as rainfall data in the last 15 years (2006-2020) were obtained from the agro meteorological unit of the Institute of Agricultural Research and Training (IAR\&T) Ibadan. Data on volume of water supplied to the areas by Oyo State Water Cooperation was also utilized in this study. Tables, graph and figure were used to enhance illustrations. Descriptive statistics, correlation and regression analysis were used. They were used to test the two hypotheses (Ho and $\mathrm{Hi}$ ) at 0.05 level of significance.

Ho: There is no relationship between rural water supply and rainfall variability in the study area.

Hi: There is a relationship between rural water supply and rainfall variability in the study area.

Analysis of variance (ANOVA) was applied to determine if there is a significant difference on available sources of water among communities.

\section{RESULTS AND DISCUSSION}

It was discovered that water demand by each household is almost similar from zone to zone which shows that the people are with similar water needs with $52.92 \%$ of the population needing 401 to 600 liters of water per day while $10.48 \%$ consumes over 800 liters of water per day (Tables 1). This shows that the people in the local government area are of similar socioeconomic status.

Table 1: Average quantity of water demand per household per day $(\mathrm{n}=40)$

\begin{tabular}{|c|c|c|c|c|c|c|c|c|}
\hline \multirow{2}{*}{ Water demand (lts) } & \multicolumn{6}{|c|}{ Zone } & \multirow{2}{*}{ Total } & \multirow{2}{*}{ Percentage } \\
\hline & 1 & 2 & 3 & 4 & 5 & 6 & & \\
\hline $200-400$ & 9 & 8 & 10 & 11 & 7 & 8 & 53 & 22.08 \\
\hline $401-600$ & 20 & 22 & 25 & 19 & 20 & 21 & 127 & 52.92 \\
\hline $601-800$ & 6 & 6 & 3 & 6 & 8 & 6 & 35 & 14.58 \\
\hline$>801$ & 5 & 4 & 2 & 4 & 5 & 5 & 22 & 10.48 \\
\hline
\end{tabular}

Source: Field survey (2020). Zone 1 - Apata, Zone 2 - Odo-Ona, Zone 3 - MKO Way, Zone 4 - Oke-Ado, Zone 5 - Iyaganku, Zone 6 Eleyele

The same trend was found in terms of water supply adequacy level where $35.83 \%$ of the respondents believed that the public water supply is fairly adequate (Table 2) and little number $(6.25 \%)$ of people believe the water supply is very adequate. The frequency distribution of different households in the zones within the local government to various sources of water is as shown in Table 3. The public water supply cannot meet quantity of water demanded by the inhabitants of the areas. This is as shown in the table as lager percentage of the people $(24.17 \%)$ relied on buying water from water vendor. It could be observed that people in the local government maximize the utilization of surface water (Ona River) and its 
tributaries probably for washing and bathing although not safe for drinking (Adetayo, 2007). It was shown from the table that $15 \%$ of the responding households obtained water through the public water supply, 20.83 $\%$ through wells, $10.42 \%$ through borehole, $22.03 \%$ through stream water and $7.5 \%$ through rain water harvesting. This indicates that rain water harvesting is not a popular source of water in the study area. This is in accordance with several researches that have revealed that in developing countries, the demand for water is hardly met (Ayoade, 1984; Chinos and Nyelong, 2005; Glantz, 1982) and according to European Commission (1998), the fulfillment of human kind's basic need for supply of safe drinking water remains an important part of today's challenges in developing countries.

Table 2: Water adequacy level in the study area

\begin{tabular}{|c|c|c|c|c|c|c|c|c|}
\hline \multirow{2}{*}{ Level of adequacy } & \multicolumn{6}{|c|}{ Zone } & \multirow{2}{*}{ Total } & \multirow{2}{*}{ Percentage } \\
\hline & 1 & 2 & 3 & 4 & 5 & 6 & & \\
\hline Grossly inadequate & 3 & 4 & 3 & 4 & 4 & 3 & 21 & 8.75 \\
\hline Inadequate & 7 & 9 & 10 & 10 & 11 & 11 & 58 & 24.17 \\
\hline Fairly adequate & 15 & 14 & 15 & 14 & 14 & 14 & 86 & 35.83 \\
\hline Adequate & 12 & 10 & 10 & 9 & 9 & 10 & 60 & 25.00 \\
\hline Very adequate & 3 & 3 & 2 & 3 & 2 & 2 & 15 & 6.25 \\
\hline
\end{tabular}

Source: Field survey (2020). Zone 1 - Apata, Zone 2 - Odo-Ona, Zone 3 - MKO Way, Zone 4 - Oke-Ado, Zone 5 - Iyaganku, Zone 6 Eleyele

Table 3: Sources of water available

\begin{tabular}{|c|c|c|c|c|c|c|c|c|}
\hline \multirow{2}{*}{ Water availability } & \multicolumn{6}{|c|}{ Zone } & \multirow{2}{*}{ Total } & \multirow{2}{*}{ Percentage } \\
\hline & 1 & 2 & 3 & 4 & 5 & 6 & & \\
\hline Public water supply & 6 & 7 & 6 & 7 & 5 & 5 & 36 & 15.00 \\
\hline Water vendor & 8 & 9 & 10 & 9 & 11 & 11 & 58 & 24.17 \\
\hline Well & 6 & 7 & 8 & 8 & 10 & 11 & 50 & 20.83 \\
\hline Borehole & 4 & 3 & 5 & 4 & 5 & 4 & 25 & 10.42 \\
\hline Stream / River & 12 & 10 & 7 & 10 & 7 & 7 & 53 & 22.03 \\
\hline Rain harvesting & 4 & 4 & 4 & 2 & 2 & 2 & 18 & 7.50 \\
\hline
\end{tabular}

Source: Field survey (2020). Zone 1 - Apata, Zone 2 - Odo-Ona, Zone 3 - MKO Way, Zone 4 - Oke-Ado, Zone 5 - Iyaganku, Zone 6 Eleyele

The relationship between public water supply and rainfall amount was shown is as shown in figure 2 . It was discovered that there is a weak but positive correlation $(r=0.321)$ between public water supply and rainfall in the study area while the regression equation is $\mathrm{Y}=-0.09 \times 2+266.5 \mathrm{x}-21708$ (where $\mathrm{X}$ is Rainfall and Y is Water supply).

Table 4: Annual Rainfall (mm) against Annual Water supply $\left(\mathrm{m}^{3} / \mathrm{yr}\right)$ for the period of 2006-2020

\begin{tabular}{l|l|l}
\hline Fear & Rainfall (mm) & Water supply $\left(\mathrm{m}^{2} / \mathrm{yr}\right)$ \\
\hline 1 & 1289.4 & 16507624 \\
2 & 1003.1 & 16804426 \\
3 & 1751.6 & 15923620 \\
4 & 1405.5 & 13649262 \\
5 & 1261.6 & 14263647 \\
6 & 1498.1 & 17624236 \\
7 & 1528.1 & 17045042 \\
8 & 1146.8 & 16613624 \\
9 & 1465.4 & 16604786 \\
10 & 1526.0 & 17246846 \\
11 & 1224.1 & 16624892 \\
12 & 1319.3 & 15862487 \\
13 & 1424.7 & 18893418 \\
14 & 1831.0 & 18862467 \\
15 & 1471.9 & 18663642 \\
\hline
\end{tabular}

Source: Agromet. Station of Institute of Agricultural Research and Training (IAR\&T) Ibadan. And Oyo State Water Corporation.

This statistical test shows that public water availability in Ibadan Southwest local government area is less vulnerable to climate change and rainfall variability.
Annual rainfall against annual water supply for the period of 15 years (2004-2018) is as presented in Table 4. Regression graph (Figure 2) was also used to further confirm the relationship between rainfall and water supply.

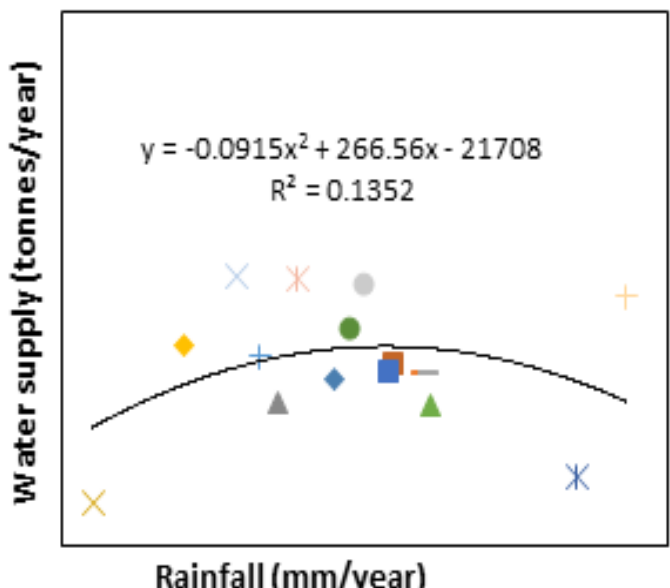

Fig 2: Regression graph of Rainfall received and Water Supply within the Study Area

The results obtained from the computation of correlation were used to test for the validity of the first hypothesis. The result shows that the calculated value (3.807) is greater than the tabulated value $(2.160)$ at 
0.05 significant levels. Therefore we reject the null hypothesis which states that there is no relationship between rural water supply and rainfall variability in the study area to accept the alternative hypothesis which states that there is a relationship between rural water supply and rainfall variability in the study area confirming that water availability and water supply is vulnerable to climate change and rainfall variability. The result is in accordance with the investigation of Eldredge et al (1998) on changing pattern of water supply for western Sudan using annual and monthly series.

Conclusion: There are variations in the annual rainfall received in the study area. Public water availability in Ibadan Southwest local government area is less vulnerable to rainfall variability. The coping strategies identified are mere survival strategies, which may not meet the required standard for optimal use of water. Due to greater dependence on the immediate environment for water supply, one promising strategy may be to develop water abstraction technologies that allow continued use of aquifers during the transition periods. I hereby recommends the enforcement of laws protecting water resources.

\section{REFERENCES}

Adetayo, AO, (2007). Impact of waste dump and industrial effluents on groundwater quality a Oluyole Estate, Beere and Bodija estate area of Ibadan metropolis. LAUTECH Journal of Engineering and Technology 4 (12): 13 - 18.

Anyadike, RNC, (1993). Seasonal and annual rainfall variations over Nigeria. International Journal of Climatology 3: 567 - 580 .

Ayoade, JO, (1984). Forecasting and managing demand for water in Nigeria. Paper presented at the $27^{\text {th }}$ annual conference of the Nigerian Geographical Association held at the University of Nigeria, Nsukka.
Eldredge. E; Ktialii, SE; Nrcholds, N; Abdalla, AA; Rydjeski, D, (1998). Changing rainfall pattern in western Sudan. Journal of Climatology 8: 45 - 53.

Glantz, M H.(1987). Drought and economic development in sub-Saharan Africa. In: (ed.) Glantz, M. H. Drought and hunger in Africa: Denying famine a future. Cambridge University Press. UK.

Ngongondo, CS. (2006). An analysis of long term rainfall variability, trends and groundwater availability in the Mulunguzi River catchment area, Zambia mountain, southern Malawi. Quaternary International 148 (1): 45 - 50.

Nnaji, A. O. (2001). Forecasting seasonal rainfall for agricultural decision making in northern Nigeria. International Journal of Agriculture and Forest Meteorology 107 (3): 193 - 205.

Nnodu, VC. (2008). Assessment of role of water and sanitation as indicators or rural poverty in Nkanu East Local Government area of Enugu State. Nigeria. In (eds.) Igbozurike, U. M.; Awuzie, U. A. and Onyenechere, E. C. Rural poverty in Nigeria. Cape Publishers, Abuja.

Odjngo, PAO. (2009). Quantifying the cost of climate change impact in Nigeria: Emphasis on wind and rainstorm. J. Human Ecol. 28 (2): 93 - 101

Odjngo, PAO. (2010). Regional evidence of climate change in Nigeria. J. Geog. Reg. Plan. 3 (6): $142-$ 150 . 